Article

\title{
The Discursive Appeal to Solidarity and Partisan Journalism in Europe's Migration Crisis
}

\author{
Stefan Wallaschek ${ }^{1,2}$ \\ ${ }^{1}$ Bremen International Graduate School of Social Sciences, University of Bremen, 28359 Bremen, Germany \\ ${ }^{2}$ Institute of Social Sciences, University of Hildesheim, 31141 Hildesheim, Germany; E-Mail: wallaschek@uni-hildesheim.de
}

Submitted: 11 January 2019 | Accepted: 29 March 2019 | Published: 27 June 2019

\begin{abstract}
The article analyses the discursive appeal to solidarity in the mass media during the unfolding of Europe's migration crisis. Solidarity was claimed by numerous actors in the public discourse to legitimise political decisions and mobilise public opinion. While it seems that the call for solidarity was shared by many actors, media studies show the 'partisan journalism' of media outlets. Thus, the political orientation of media outlets influences their coverage of public debates. Hence, to what extent do different quality newspapers cover the same solidarity claims in times of crisis? In order to answer this question, the crisis coverage of two German and two Irish newspapers with centre-left and centre-right political orientations is examined via the discourse network methodology. Germany is selected due to high political parallelism and a strong affectedness by the crisis, while Ireland is selected because of low political parallelism and a weak affectedness by the migration crisis. The findings demonstrate that partisan journalism persists during Europe's migration crisis. Especially German party actors are present in both countries, underpinning the central position of Germany. Regarding the appeal to solidarity, political solidarity claims prevail in all four newspapers, indicating the political-institutional asymmetry in the Common European Asylum System. The study contributes to the strategic framing of concepts in public debates and demonstrates that the left-right distinction of media outlets is hardly affected by the migration crisis.
\end{abstract}

\section{Keywords}

discourse networks; Europe; Germany; Ireland; migration crisis; partisan journalism; solidarity

\section{Issue}

This article is part of the issue "The European Refugee Controversy: Civil Solidarity, Cultural Imaginaries and Political Change", edited by Gert Verschraegen (University of Antwerp, Belgium) and Robin Vandevoordt (University of Oxford, UK/University of Antwerp, Belgium).

(C) 2019 by the author; licensee Cogitatio (Lisbon, Portugal). This article is licensed under a Creative Commons Attribution 4.0 International License (CC BY).

\section{Introduction}

Solidarity was a buzzword in Europe's migration crisis in 2015. Numerous actors claimed solidarity with refugees and called for solidarity among member states of the European Union (EU). Commentators called the time period from August to October 2015 the 'long summer of migration' and appreciated volunteering by citizens across Europe (Della Porta, 2018; Hamann \& Karakayali, 2016; Kasparek \& Speer, 2015; Wallaschek, 2018). Other studies showed that the public discourse during the crisis rather focused on security and economic frames (Greussing \& Boomgaarden, 2017; Rheindorf \& Wodak, 2018). Hence, media outlets report about the crisis in dif- ferent ways. One reason for this is 'partisan journalism'. Media news coverage and commentaries are influenced by political ideologies which lead to a specific framing of issues in the respective newspapers (Brüggemann, Engesser, Büchel, Humprecht, \& Castro, 2014; Hallin \& Mancini, 2004; van der Pas, van der Brug, \& Vliegenthart, 2017). Moreover, journalists quote and interview other actors to support their own opinions (Hagen, 1993). The question is then whether ideological differences between media outlets vanish or increase during the crisis? To what extent can a discursive contestation of solidarity and security frames be observed?

The article investigates the solidarity discourse in two German and two Irish daily quality newspapers in 2014 
and 2015. One centre-right (Welt, Irish Independent) and one centre-left (Süddeutsche Zeitung [SZ], Irish Times) newspaper in each country is selected to analyse the different political orientations as well as different models of political parallelism. While Germany was strongly affected by the migrant crisis in 2015, receiving hundreds of thousands of asylum seekers within a few months, Ireland hardly received any refugees which is mostly due to the geographical location of the island (European Commission, 2017). Regarding political parallelism, Germany is sorted into the Northern European democratic corporatist media model that assumes a close relationship between party organisations and press outlets. Ireland, however, is included in the North Atlantic liberal model which assumes the press and party organisations to be rather distant (Hallin \& Mancini, 2004). Accordingly, both countries have been affected differently by the migration crisis in 2015 and follow different versions of political parallelism.

I analyse the framing in the media outlets by applying the discourse network methodology. This method combines discourse analysis and social network analysis by examining the interdependent process of actor presence and concept formation in public discourses (Leifeld, 2016). I analyse which actors are present in the newspapers and which frames are deployed. Since solidarity is understood as 'contested concept' (Gallie, 1956), I focus on different meanings of solidarity and which concepts are most present during the migration crisis discourse. First, I demonstrate that party actors, national executives and EU representatives dominate the solidarity discourse. The partisan journalism persists in both countries during the migration crisis. Second, I show that political solidarity is a shared claim in the four selected newspapers despite the different political orientations of the media outlets. The study demonstrates that the actor constellation corroborates previous work on partisan journalism and 'opportune witnesses' while the omnipresent discursive appeal to solidarity challenges the expectation that solidarity is predominantly invoked by leftist actors.

The article proceeds as follows: In the next section, I briefly outline the research on partisan journalism and Europe's migration crisis. Thereafter, I describe the data and the discourse network methodology. The next section presents the results of the discourse network analysis, followed by a discussion of the findings and implications of the study.

\section{Partisan Journalism}

Previous studies show that media outlets have a political orientation which impacts their news coverage. The seminal work by Hallin and Mancini (2004, p. 21) refers to political parallelism as "the degree and nature of the links between the media and political parties or, more broadly, the extent to which the media system reflects the major political divisions in society". Hence, journalists do not cover news in a neutral way, but mostly fol- low the general political orientation of the media outlet (Hagen, 1993). Hallin and Mancini (2004) distinguish between a Northern European democratic corporatist media model, a Mediterranean polarised pluralist model, and a North Atlantic liberal model. Regarding the dimension of political parallelism, the first two models share the high alignment between party organisations and the press whilst the North Atlantic liberal model assumes a rather distant relationship between party and press due to a loose tradition of party presses. Brüggemann et al. (2014) revised the typology by Hallin and Mancini and added a fourth media system. Nonetheless, Germany and Ireland are prototypical cases for the democratic corporatist model (Germany) and the liberal model (Ireland) which offers the opportunity to compare both cases with regard to different modes of political parallelism.

Most studies analyse the appearance of specific parties in the respective newspapers and the issue framing in order to observe a close or distant alignment of party actors and the press (Berkel, 2006; Brüggemann et al., 2014; van der Pas et al., 2017). However, as others argue, this is a rather narrow understanding of political parallelism. Political orientation is not only reflected in party actors' statements in the media and party actors are not the only actor group in the media. Broadening the scope of the analysis shows that other actors also appear in the newspapers that are ideologically close to the political orientation of the media outlet (Allern \& Blach- Ørsten, 2011; Kaiser \& Kleinen-von Königslöw, 2019). Hagen (1993) describes this strategy as calling "opportune witnesses" since journalists do not report balanced or objectively about an event, but are rather biased in their selection of interview partners and the representation of quotes. Additionally, specific nationaloriented frames might guide the news coverage more than political ideology. Especially in times of crisis, the degree to which a country is affected by the crisis might be more relevant for the media coverage than the political orientation of the outlet (Salgado \& Nienstedt, 2016).

Accordingly, I expect that more party actors appear in the German newspapers' coverage than in that of the Irish newspapers. Additionally, I expect that centreleft newspapers (SZ, Irish Times) tend to feature actors from the left political spectrum to a greater extent while centre-right newspapers (Welt, Irish Independent) give more actors from the right political spectrum a voice in their coverage of Europe's migration crisis.

\section{Security and Solidarity Frames in Europe's Migration Crisis}

Studies on Europe's migration crisis have mainly exhibited two aspects: Firstly, scholars demonstrated the incompleteness of the European migration policy, and secondly, they highlighted the public debate on a security and solidarity framing of the migration crisis.

The EU's lack of supranational authority in dealing with Europe's migration crisis has been noted (Genschel 
\& Jachtenfuchs, 2018). The EU has developed a Common European Asylum System (CEAS) to harmonise the different national migration policies across Europe, but the European Council is still the main institutional body that decides on the rules and further political development of this policy area. Moreover, the member states are still the main regulators by setting norms and rules (Zaun, 2016). Europe's migration and asylum policy is based on three principles of the Dublin Regulations: First, the member state in which an asylum seeker first enters the EU has to deal with its asylum claim. This regulation gives the border countries of the EU, especially Spain, Italy, and Greece, a one-sided responsibility. Second, the Dublin Regulations try to avoid an ambivalent legal status of asylum seekers by attributing the responsibility to deal with the asylum claim to one country. Third, asylum seekers cannot claim asylum in more than one member state simultaneously or try to get asylum in another member state after the first rejection. However, this leads to the fact that claiming asylum in non-border EU countries such as Germany or Ireland is made almost impossible (Chetail, 2016). Or as Bast (2013) sums up the institutional discrepancy: "In the European treaties it is expressly mentioned that there must be solidarity among the EU member-states in terms of burdensharing-but this organizational task has not yet been implemented. There is no asylum system based on solidarity." Hence, while solidarity is a guiding principle in the Lisbon Treaty, the current EU asylum policies are hardly perceived as solidary.

Scholars investigated how the migration crisis was depicted in the public debate. They show that security and economic frames prevailed in the media while humanitarian claims were rather marginal (Greussing \& Boomgaarden, 2017). Others demonstrate how security measures such as border surveillance were depicted as humanitarian acts and indicate a discursive shift towards right-wing populism (Colombo, 2018; Musarò \& Parmiggiani, 2017; Rheindorf \& Wodak, 2018). Furthermore, solidarity movements and pro-refugee protests were quite visible and active during the crisis. They influenced public opinion, mobilised citizens to help refugees and therefore shaped the perception of the migration crisis substantially (Della Porta, 2018; Karakayali, 2017; Lahusen \& Grasso, 2018). The image of Alan Kurdi, a 3-year-old boy who was found dead at the Turkish coast received massive media attention and created a public outcry about the dangerous route to Europe and the lack of solidarity with refugees. The 'We can do it' ('Wir schaffen das') statement by German Chancellor Angela Merkel regarding the reception of hundreds of thousands of refugees stuck in Hungary created a very positive (but volatile) public opinion on receiving refugees who are in need of protection (Vollmer \& Karakayali, 2018). While the call to solidarity strongly resonated with the public, there has been little investigation into how actors frame solidarity (Closa \& Maatsch, 2014; TransSOL, 2018). Therefore, I build upon research that looks at the discursive construction of solidarity (Wallaschek, 2019) and differentiates solidarity into various meanings. For the present study, four meanings of solidarity are most relevant: Political solidarity refers to new institutional mechanisms and instruments that foster cooperation; cultural solidarity promotes supportive action for shared norms and identity; monetary solidarity is based on risksharing and financial support for others; and lastly, social solidarity claims to redistribute resources and refers to voluntary actions by individuals and social groups.

These four meanings are expected to be present in the migration crisis, because of the asymmetrical CEAS and the need for new institutional instruments (political solidarity). The EU asylum policy strongly rests on human rights and solidarity as a guiding principle in the Lisbon Treaty (cultural solidarity). Financial help as humanitarian aid or to other member states dealing with incoming asylum seekers is important during the crisis (monetary solidarity). The voluntary actions by citizens and activists helping refugees as well as social policy measures might feature in the public discourse (social solidarity).

Accordingly, I expect that meanings of solidarity are more prominent in centre-left newspapers than in centreright newspapers. Conversely, l expect that non-solidarity claims are more prominent in centre-right newspapers than in centre-left newspapers.

\section{Data and Methods}

The study analyses the migration crisis coverage of four newspapers, two daily quality newspapers in each country (Germany and Ireland) in the years 2014 and 2015. While the analyses of Europe's migration crisis often begin in 2015 (Greussing \& Boomgaarden, 2017; Vollmer \& Karakayali, 2018), the first signs of the migration crisis emerged before 2015. The 'Mare Nostrum' mission of the Italian Navy started in October 2013 after a tragic shipwreck on the coast of Lampedusa in which more than 360 migrants died. Mare Nostrum lasted for a year and saved approximately 150,000 migrants. The Italian government urged the EU to establish a follow-up mission. While the Italian mission was a 'save and rescue' mission, the following Frontex-led mission 'Triton' was oriented towards 'sea border protection' (EPSC, 2017). Lasting conflicts and civil wars in the Middle East (Syria) and Northern and Eastern Africa (Libya, Somalia, Eritrea) prompted further migration movements towards Europe. In 2015, more than one million migrants reached EU territory while at the same time approximately 3,800 people died in the Mediterranean. Nonetheless, the EU did not agree on a substantial reform of the Dublin system or EU migration and asylum policy in general. The European Commission's proposal to relocate 160,000 registered refugees across the member states was approved by the European Council by majoritarian vote, but the current numbers of relocation show that hardly any member state completely fulfilled its obligations (European Commission, 2017). 
The four selected newspapers are the German newspapers SZ and Welt, and the Irish newspapers Irish Times and Irish Independent. They have a large readership, a nationwide circulation and represent the different political ideologies of centre-left (SZ and Irish Times) and centre-right orientation (Welt and Irish Times). Choosing the Welt instead of the FAZ as the German centreright newspaper is based on previous work that demonstrates that SZ and Welt differ more on migration policy issues than SZ and FAZ (Eilders, 2002). Hence, partisan journalism on solidarity during the migration crisis might be more pronounced between SZ and Welt.

Quality newspapers still have an agenda-setting function and strongly influence the public debate with their comments, interviews and reports on political issues. Moreover, quality newspapers cover more political and policy-related issues than tabloids (Koopmans, 2007; Nossek, Adoni, \& Nimrod, 2015; Reinemann, Stanyer, Scherr, \& Legnante, 2012). The newspaper articles have been coded by applying the political claims analysis (Koopmans \& Statham, 1999). Rather than coding the entire article, it focuses on the specific claims made by actors. Claims are defined as "the purposive and public articulation of political demands, calls to action, proposals, criticisms or physical attacks, which, actually or potentially, affect the interests or integrity of the claimants and/or other collective actors." (Koopmans, 2007, p. 189). This study is not only interested in the claimant (actor) who makes a statement on a specific issue, but also in the justification the claimant uses (de Wilde, 2013). By focusing on this aspect, the partisan journalism as well as the framing of solidarity are examined.

The selection of newspaper articles is based on a nominalistic approach and thereby the keyword search string includes the term 'solidar*' or close synonyms. I selected 967 articles in the four newspapers via the database Factiva and coded 633 claims. Using a nominalistic approach reduces the number of articles and sets a rather high threshold to select newspaper articles. Since the study is interested in how actors frame solidarity, using the term 'solidar*' in the search string increases the likelihood of retrieving the most relevant articles during the migration crisis. Table 1 summarises the number of claims in the four newspapers in each year.
This overview shows that German newspapers cover more claims than Irish newspapers, which reflects Germany's strong affectedness by the crisis and the public relevance and interest in the topic. Nonetheless, the number of claims increases in the Irish newspapers from 2014 to 2015 which shows that Europe's migration crisis gained media attention in peripheral countries not directly affected by the crisis.

The discourse network methodology is deployed to study the co-occurrence of framing and actor appearance in the selected media. It takes into account that actors refer to certain frames in their claims which might be shared by other actors in the public debate. These actor-frame relations are studied in discourse network analyses (Leifeld, 2016; Leifeld \& Haunss, 2012). This perspective highlights agenda-setting processes and how actors frame public debates. Accordingly, the discourse network structure is a two-mode network, because two types of nodes (actor and concepts) appear in the network. Only those claims are used for the discourse network analysis in which actors justify their claim. This reduces the number of claims that are analysed, because claims without a justification have been coded as 'no justification' and are not considered in this study.

To account for the most present actors and concepts, the eigenvector centrality is calculated. It measures how central a node is in a network by counting the number of edges between two nodes and considering whether the node is linked to other central nodes in the network. The scale ranges from 0 to 1 and the closer the value is to 1 , the more central the node is (Bonacich, 1987). The network statistics are calculated and the network figures are visualised with the R package igraph (Csardi \& Nepusz, 2006).

\section{Results}

The findings are presented in the order of the articulated expectations in Sections 2 and 3. First, I turn to political parallelism and then focus on the framing in the four newspapers. The expectation was that more party actors appear in German than in Irish newspapers on the solidarity debate during Europe's migration crisis. Additionally, due to the political orientation of the newspaper, more left or right party actors are featured in

Table 1. Number of claims in German and Irish newspapers, 2014-2015.

\begin{tabular}{lrrrrr}
\hline Year\Newspaper & SZ & Welt & IT & IInd & Total \\
\hline $\mathbf{2 0 1 4}$ & 54 & 74 & 10 & 2 & 140 \\
$\mathbf{2 0 1 5}$ & 219 & 138 & 87 & 49 & 493 \\
\hline Total & 273 & 212 & 97 & 51 & 633 \\
\hline
\end{tabular}

Notes: SZ: Süddeutsche Zeitung, Welt: Die Welt, IT: Irish Times, IInd: Irish Independent. For the German migration crisis debate, I used the following keyword string in the database Factiva: 'Flüchtling* or Flucht* or Migrant* or Einwander* or Zuwander* or Asyl*) and Solidar* and (EU or Europ*)'. For the Irish migration crisis debate: '(Refugee or escape or Migrant* or Migration* or Immigrant or Immigration* or Asyl*) and (solidar* or mutual w/1 support* or cooperat*) and (EU or Europ*)'. An asterisk controls for multiple endings of a word. Duplicates of articles were excluded from the article population. 
the newspapers with a similar political ideology. In order to give an overview of the different discourse networks, Table 2 summarises the network statistics of the four newspapers.

\subsection{Political Parallelism and Partisan Journalism}

The differences in the representation of party actors between the newspapers is rather marginal. 64 per cent of all actors in German newspapers are party actors while 60 per cent of actors have a party affiliation in the Irish newspapers. The centre-right newspaper Welt features, with a share of 76 per cent, the highest number of party actors. German newspapers predominantly cover claims from domestic party actors, although some EU actors (Juncker, Avramopoulos) are also present. The Irish newspapers feature Irish party actors, but also represent other European party actors like German politician FrankWalter Steinmeier (SPD) or EU actors like Jean-Claude Juncker. Thus, the first expectation is not corroborated. Both Irish and German newspapers focus on party actors in the migration crisis discourse.

The representation of centre-left and centre-right actors follows the expected direction. The centre-left newspaper SZ features actors who are ideologically close to the SZ like the Catholic cardinal Marx or the SPD. The Welt covers more claims from centre-right actors like German Chancellor Merkel or Minister of Interior Thomas de Maizière (both CDU). Nonetheless, the most central actors in both German newspapers are conservative politicians (Merkel, de Maizière, CDU, CSU, Avramopoulos) while centre-left actors are less visible in the discourse. These conservative politicians have central policy-related competences and thereby get more public attention from the media outlets. Hence, the expectation in relation to 'opportune witnesses' is mainly corroborated for the German case, but it is also affected by the involvement of conservative politicians in government coalitions during the time period.

In the Irish case, the Irish Times focuses less on domestic party actors than the Irish Independent. However, the latter covers the solidarity debate in Europe's migration crisis to a lesser extent. If the Irish centre-right newspaper covers solidarity, party actors predominantly appear. Moreover, these party actors have a centre-right political orientation. More and different actors appear in the Irish Times, but there are hardly any left-leaning party actors. Nonetheless, more pro-refugee groups (e.g. Amnesty, Irish Refugee Council) are represented in the Irish Times. Hence, the expectations for the Irish newspapers can be almost completely corroborated. The Irish Independent represents more party actors than expected but features more claims by centre-right (party) actors. The Irish Times represents, as expected, not many party actors and covers more claims by centre-left actors.

\subsection{Framing Pro- and Contra-Solidarity}

The following section focuses on the framing in the solidarity debate. The expectation was that solidarity frames appear more likely and more pronounced in centre-left newspapers than in centre-right newspapers. Figures 1 and 2 show, however, that political solidarity dominates the discourse in the four newspapers and this is underlined by the eigenvector value of 1 in Table 2. This demonstrates the positive discursive appeal to solidarity. If actors refer to solidarity, then they seldom contest this concept, but support solidary actions in their claims.

Most actors in the four newspapers refer positively to solidarity and demand a reform of existing regulations. After a dozen migrants were found dead in a lorry on a highway in Austria in August 2015, the Irish Independent reports the political reactions and cites German Chancellor Angela Merkel:

Ms Merkel told a news conference at the summit on the West Balkans in Vienna: "We are of course all shaken by the appalling news. This reminds us that we must tackle quickly the issue of immigration and in a European spirit-that means in a spirit of solidarityand to find solutions." (Irish Independent, 2015)

Table 2. Network statistics about the four discourse networks.

\begin{tabular}{lllll}
\hline & SZ & Welt & IT & Ind \\
\hline Number of actors & 33 & 21 & 29 & 15 \\
\hline Number of edges & 90 & 58 & 51 & 18 \\
\hline Main component & 41 nodes & 25 nodes & 32 nodes & 16 nodes \\
\hline Degree centralisation & 0.37 & 0.39 & 0.44 & 0.47 \\
\hline Network density & 3.32 & 3.12 & 2.31 & 1.9 \\
\hline Most central concept & $\begin{array}{l}1.00 \\
\text { (political solidarity) }\end{array}$ & $\begin{array}{l}1.00 \\
\text { (political solidarity) }\end{array}$ & $\begin{array}{l}\text { (political solidarity) } \\
\text { (political solidarity) }\end{array}$ \\
\hline
\end{tabular}

Notes: SZ: Süddeutsche Zeitung, Welt: Die Welt, IT: Irish Times, IInd: Irish Independent. A threshold for the eigenvector centrality of the nodes is applied to focus on the most visible actors in the respective network. Only nodes with an eigenvector centrality of at least 0.1 appear in the discourse networks. Following De Nooy, Mrvar and Batagelj (2011), the network density for two-mode networks is computed as the mean degree centrality of the respective network. 


\section{SZ, 2014-2015}

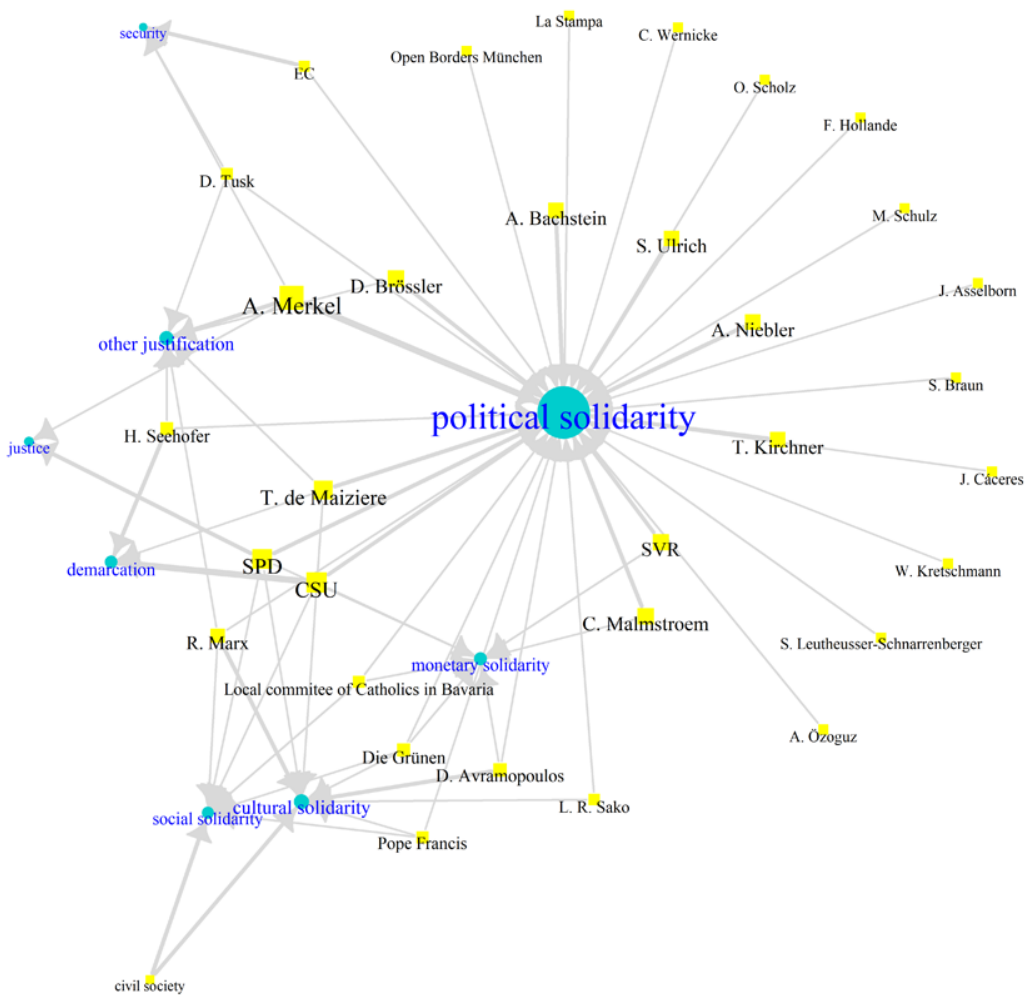

Welt, 2014-2015

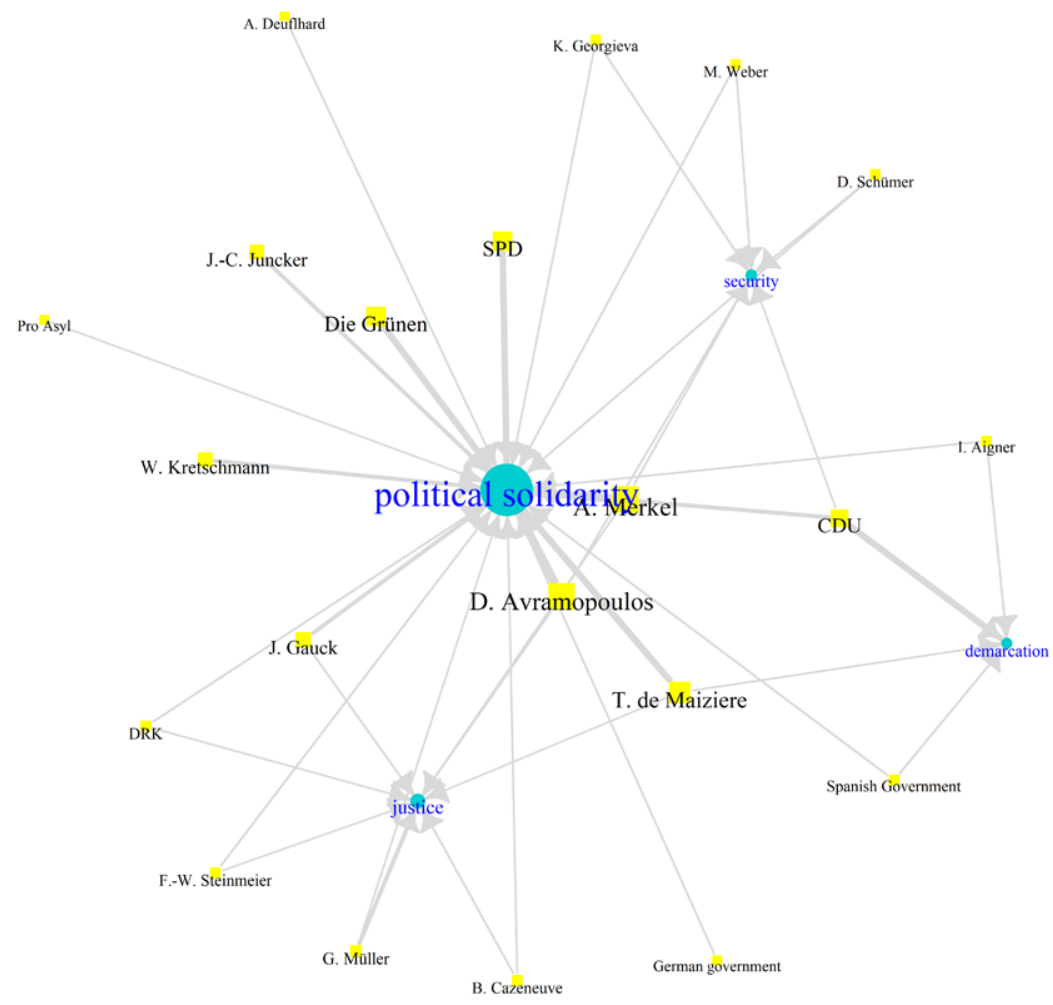

Figure 1. Discourse networks in the German newspapers (SZ, Welt). Notes: The graph depicts concepts as circles and actors as squares. The size of the nodes indicates the eigenvector centrality. The bigger the node, the more central it is. The thickness of the edges shows how often an actor refers to a concept. The bigger the edge, the more often the actors uses the concept. 
Irish Independent, 2014-2015
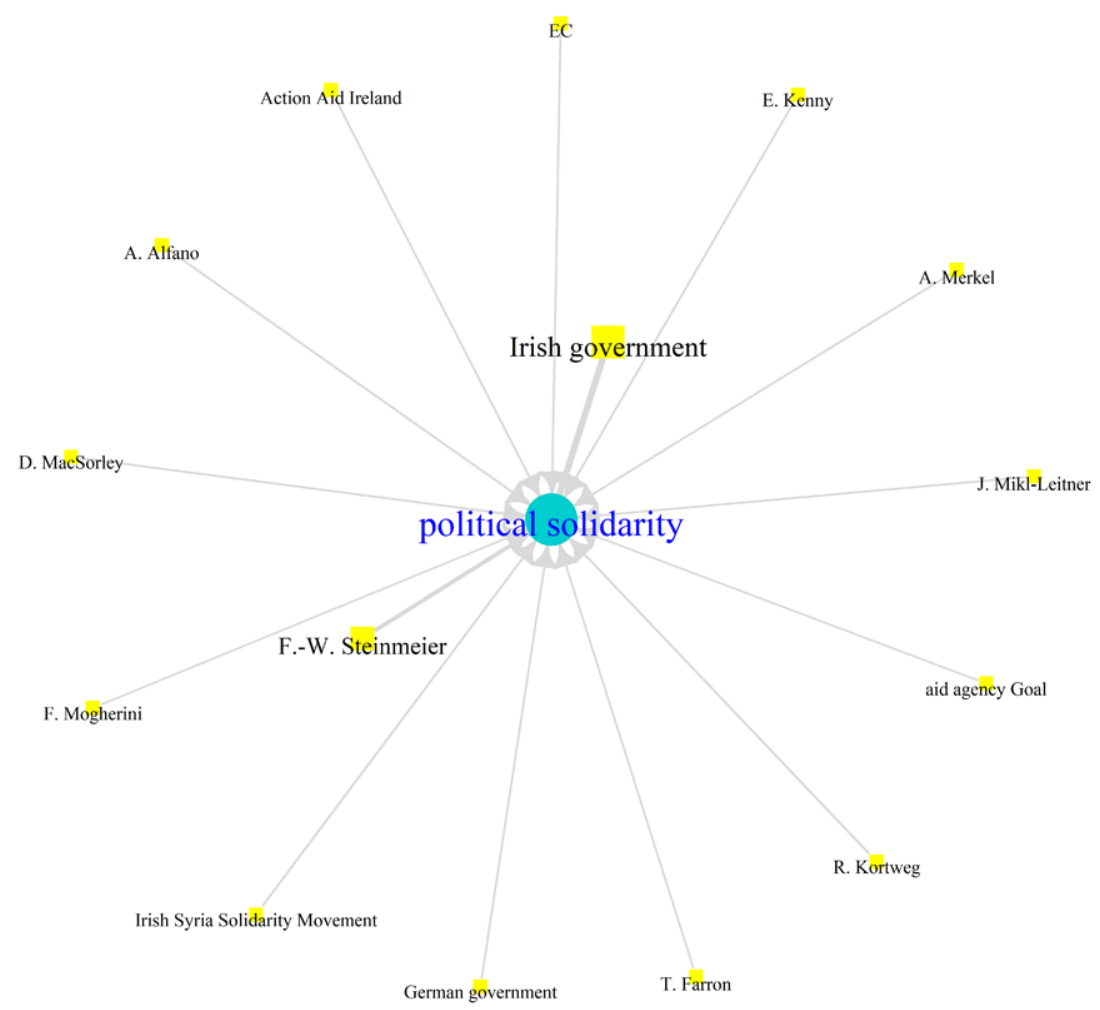

Irish Times, 2014-2015

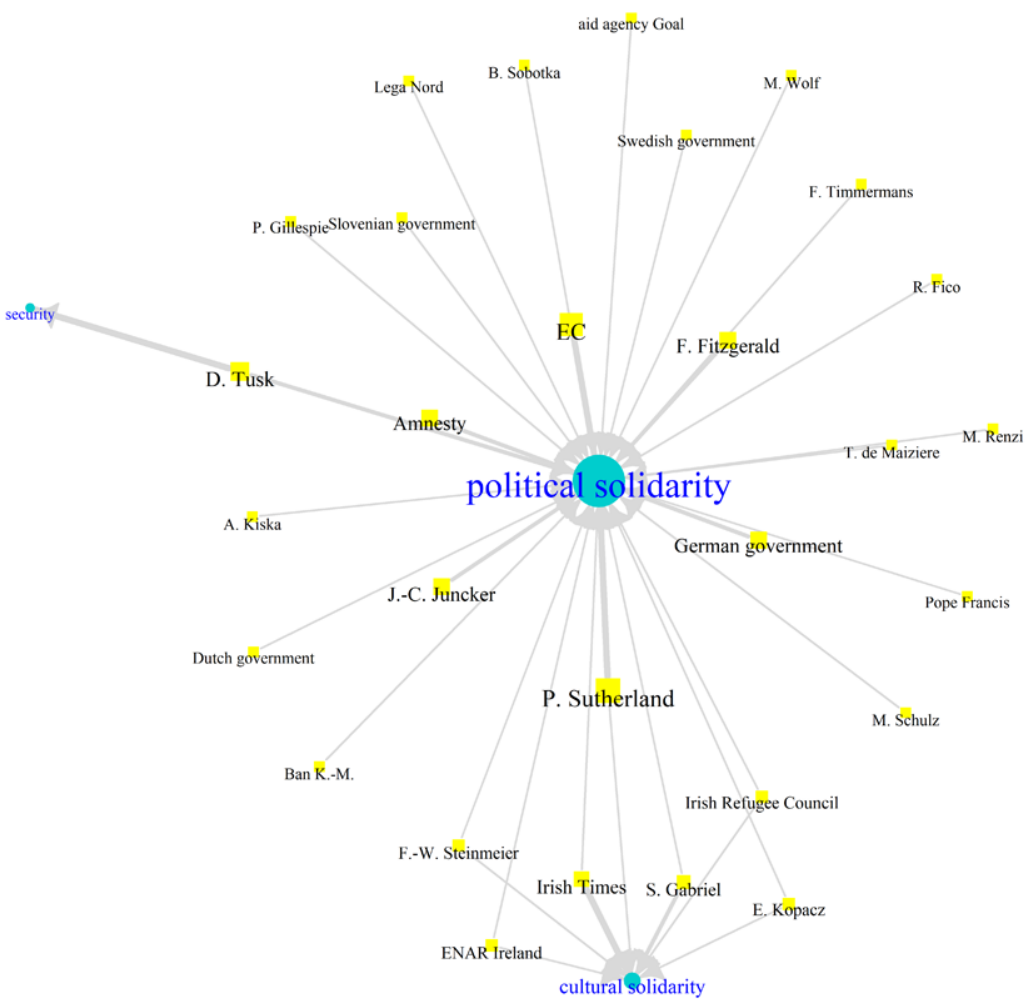

Figure 2. Discourse networks in the Irish newspapers (Irish Independent, Irish Times). Notes: The graph depicts concepts as circles and actors as squares. The size of the nodes indicates the eigenvector centrality. The bigger the node, the more central it is. The thickness of the edges shows how often an actor refers to a concept. The bigger the edge, the more often the actors uses the concept. 
Political solidarity is in particular linked to solidarity among EU member states. These claims show that the national governments are aware that the current Dublin Regulations do not properly work if hundreds of thousands of people try to claim asylum in the EU. They attribute too much responsibility to EU border countries in dealing with migrants and asylum seekers. Moreover, Greece and Italy had been hit hard by the Euro crisis and did not have the capacities to host and deal with the large number of refugees. Therefore, many actors demanded more (political) solidarity with Italy and Greece. In 2014, Dimitris Avramopoulos, the designated European Commissioner for Migration, Home Affairs and Citizenship at the time, claimed:

"We have to show solidarity with Italy", said Avramopoulos at his hearing with members of the European Parliament. Clear asylum regulations, measures against illegal immigration and human traffickers as well as more opportunities for legal immigration are necessary.....taly and Greece feel disadvantaged [due to the Dublin Regulations]. (Welt, 2014)

Solidarity claims also address the cultural dimension, promoting equal rights and demanding more moral support for refugees. Pope Francis publicly demands more support and empathy regarding refugees, the Irish Times reports on a call to demonstrations by pro-refugee and civil society groups in Ireland to show solidarity with refugees while:

"It cannot be accepted that the Mediterranean becomes a big graveyard", he [Pope Francis] said. "The boats, that daily arrive at the coasts of Europe, are filled with men and women who need empathy and help." (SZ, 2014)

Today [September 5th 2015] has been declared a Day of Action in solidarity with people seeking refuge in Europe. The Irish Refugee Council and Migrant Rights Centre Ireland have called on people to gather at the Famine Memorial on Dublin's Custom House Quay at $1 \mathrm{pm}$ to show their solidarity with refugees. (Irish Times, 2015a)

Non-solidarity frames are present in the discourse, but rather on the margins despite the political orientation of the newspaper. Actors hardly oppose solidarity claims directly. Rather, they try to reinterpret the crisis by emphasising security and demarcation frames in their public claims. Especially conservative politicians claim both, namely more solidarity in the crisis and increasingly emphasising security issues. For instance, the president of the European Council Donald Tusk demanded a stronger emphasis on border surveillance in October 2015 as the Irish Times reports:

Mr Tusk, who has steered the EU towards a more hardline approach to the refugee crisis in recent weeks, reiterated the need for Europe to reinforce its external borders. "Today, no task is more important for the moderate centre right than the re-establishment of Europe's external borders," he said. "We can no longer allow solidarity to be equivalent to naivety, openness to be equivalent to helplessness, freedom to be equivalent to chaos." (Irish Times, 2015b)

To sum up, the expectation that solidarity claims are more likely to be prevalent in centre-left newspapers than in centre-right newspapers is not corroborated in either country. Instead, the positive discursive appeal to (political) solidarity is observable in the German and Irish newspapers during Europe's migration crisis.

\section{Conclusion}

The article analysed the solidarity debate in German and Irish newspapers in the midst of Europe's migration crisis. It highlighted the actor constellation in the public discourses and how actors frame solidarity. It is the first study to focus on the influence of partisan journalism on the coverage of the solidarity debate in Europe's migration crisis.

The article provides three novel insights into the study of political parallelism, the research on solidarity and Europe's migration crisis. Firstly, the article highlights that the left-right orientation of newspapers persists. Although a crisis might be understood as a 'critical juncture' that changes institutional settings and leads to a redefining of positions, centre-right and centre-left newspapers feature 'opportune witnesses' in their news coverage. Moreover, both Irish and German newspapers predominately feature party actors, mainly domestic government actors, in their news coverage. Hence, the study corroborates the 'structural bias' of newspapers towards the representation of government actors as well as the fact that government actors are the winners of Europeanised public debates (Koopmans, 2007; Van Dalen, 2012).

Secondly, solidarity seems to be everybody's preferred concept. If political actors refer to this concept, it is in a rather positive valence. It is rather unusual to openly reject the call for solidarity and claim that it is not necessary or falsely claimed. This prompts the question as to why this is the case, especially if the recent crises are strongly linked to the conflict over solidarity in the EU (Hutter, Grande, \& Kriesi, 2016). One reason might be the historical legacy of the concept. Solidarity is an important concept in the labour movement but also in Catholic social teaching. Moreover, it is one of the fundamental norms in European countries (Featherstone, 2012; Sangiovanni, 2013; Stjernø, 2009). Hence, publicly rejecting solidarity seems rather unlikely. Instead, the discursive battle is about the interpretation of solidarity, how solidarity is framed and with whom solidarity is (not) expressed.

Lastly, the study demonstrated that political solidarity is the common denominator in the public debate. Re- 
forming the existing CEAS and supporting border countries are fiercely debated among actors. However, the (non-)reform of the CEAS and the failed implementation of an EU-wide quota to relocate refugees across member states (Biermann, Guérin, Jagdhuber, Rittberger, \& Weiss, 2019; Zaun, 2018) demonstrate that political solidarity failed to be institutionalised. It created public awareness about the pitfalls of the policy area, but the opposition of several member states led to the failure of political solidarity after 2015. Nonetheless, these political conflicts are crucial for the future development of the Home and Justice Affairs of the EU as well as in the societal handling of refugees and migrants in European countries.

The study also bears some limitations. Focusing only on a rather short time period might exaggerate the general level of public solidarity claims. Hence, future studies might take a more extensive historical perspective on the framing of solidarity which goes beyond a crisis period. Moreover, further analyses could focus on online and social media in order to study the appeal to solidarity in media outlets beyond the mainstream media. Quality newspapers have a selection bias towards certain frames and powerful actors. Lastly, the study only considered articles and claims that contained solidarity or close synonyms for the subsequent analysis. Using a more general approach to investigate norms and values in public debates can illuminate the framing structure and use of such concepts in public discourses.

\section{Acknowledgments}

I would like to thank Regina Becker, Leslie Gauditz, Jakob Henninger and Sandra Reinecke for crucial feedback on an earlier version of the article. I am also grateful to the anonymous reviewers and editors for giving constructive comments on the text. This work was supported by the German Research Foundation (DFG) in the Project GSC 263.

\section{Conflict of Interests}

The author declares no conflict of interests

\section{References}

Allern, S., \& Blach- $\varnothing$ rsten, M. (2011). The news media as a political institution: A Scandinavian perspective. Journalism Studies, 12(1), 92-105. https://doi.org/ 10.1080/1461670X.2010.511958

Bast, J. (2013). In Europe there is no solidarity in terms of the asylum system. Verfassungsblog. Retrieved from http://verfassungsblog.de/in-europe-there-isno-solidarity-in-terms-of-the-asylum-system

Berkel, B. (2006). Political parallelism in news and commentaries on the Haider conflict. A comparative analysis of Austrian, British, German, and French quality newspapers. Communications, 31(1). https://doi.
org/10.1515/COMMUN.2006.006

Biermann, F., Guérin, N., Jagdhuber, S., Rittberger, B., \& Weiss, M. (2019). Political (non-)reform in the euro crisis and the refugee crisis: A liberal intergovernmentalist explanation. Journal of European Public Policy, 26(2), 246-266. https://doi.org/10.1080/13501763. 2017.1408670

Bonacich, P. (1987). Power and centrality: A family of measures. American Journal of Sociology, 9(5), 1170-1182.

Brüggemann, M., Engesser, S., Büchel, F., Humprecht, E., \& Castro, L. (2014). Hallin and Mancini revisited: Four empirical types of Western media systems. Journal of Communication, 64(6), 1037-1065. https://doi.org/ 10.1111/jcom.12127

Chetail, V. (2016). Looking beyond the rhetoric of the refugee crisis: The failed reform of the Common European Asylum System. European Journal of Human Rights, 1(5), 584-602.

Closa, C., \& Maatsch, A. (2014). In a spirit of solidarity? Justifying the European Financial Stability Facility (EFSF) in national parliamentary debates. JCMS: Journal of Common Market Studies, 52(4), 826-842. https://doi.org/10.1111/jcms.12119

Colombo, M. (2018). The representation of the "European Refugee Crisis" in Italy: Domopolitics, securitization, and humanitarian communication in political and media discourses. Journal of Immigrant \& Refugee Studies, 16(1/2), 161-178. https://doi.org/ 10.1080/15562948.2017.1317896

Csardi, G., \& Nepusz, T. (2006). The igraph software package for complex network research. InterJournal, Complex Systems, 1695(5), 1-9.

de Wilde, P. (2013). Representative claims analysis: Theory meets method. Journal of European Public Policy, 20(2), 278-294. https://doi.org/10.1080/13501763. 2013.746128

De Nooy, W., Mrvar, A., \& Batagelj, V. (2011). Exploratory social network analysis with Paje. In Structural analysis in the social sciences (Vol. 34). Cambridge: Cambridge University Press.

Della Porta, D. (Ed.). (2018). Solidarity mobilizations in the 'refugee crisis': Contentious moves. Cham: Palgrave Macmillan.

Eilders, C. (2002). Conflict and consonance in media opinion: Political positions of five German quality newspapers. European Journal of Communication, 17(1), 25-63.

EPSC. (2017). Irregular migration via the Central Mediterranean (EPSC Strategic Notes, No. 22). Retrieved from https://ec.europa.eu/epsc/sites/epsc/files/ strategic_note_issue_22_0.pdf

European Commission. (2017). Relocation: EU solidarity between member states (November 2017). Retrieved from https://ec.europa.eu/home-affairs/ sites/homeaffairs/files/what-we-do/policies/ european-agenda-migration/20171114_relocation_ eu_solidarity_between_member_states_en.pdf 
Featherstone, D. (2012). Solidarity: Hidden histories and geographies of internationalism. London: Zed Books.

Gallie, W. B. (1956). Essentially contested concepts. Proceedings of the Aristotelian Society, 56, 167-198.

Greussing, E., \& Boomgaarden, H. G. (2017). Shifting the refugee narrative? An automated frame analysis of Europe's 2015 refugee crisis. Journal of Ethnic and Migration Studies, 43(11), 1749-1774. https://doi.org/ 10.1080/1369183X.2017.1282813

Genschel, P., \& Jachtenfuchs, M. (2018). From market integration to core state powers: The Eurozone crisis, the refugee crisis and integration theory. JCMS: Journal of Common Market Studies, 56(1), 178-196. https://doi.org/10.1111/jcms.12654

Hagen, L. M. (1993). Opportune witnesses: An analysis of balance in the selection of sources and arguments in the leading German newspapers' coverage of the census Issue. European Journal of Communication, 8(3), 317-343. https://doi.org/10.1177/ 0267323193008003004

Hallin, D. C., \& Mancini, P. (2004). Comparing media systems: Three models of media and politics. In Communication, society, and politics. Cambridge: Cambridge University Press.

Hamann, U., \& Karakayali, S. (2016). Practicing Willkommenskultur: Migration and solidarity in Germany. Intersections: East European Journal of Society and Politics, 2(4), 69-86.

Hutter, S., Grande, E., \& Kriesi, H. (Eds.). (2016). Politicising Europe: Integration and mass politics. Cambridge: Cambridge University Press.

Irish Independent. (2015, August 28). Austrian police find dozens of migrants dead in parked truck. Irish Independent. Retrieved from www.factiva.com

Irish Times. (2015a, September 5). Solidarity to be shown in Day of Action. Irish Times. Retrieved from www. factiva.com

Irish Times. (2015b, October 23). 'We cannot simply push away boats', says Merkel; German chancellor calls on EU members to share. Irish Times. Retrieved from www.factiva.com

Kaiser, J., \& Kleinen-von Königslöw, K. (2019). Partisan journalism and the issue framing of the Euro crisis: Comparing political parallelism of German and Spanish online news. Journalism, 20(2), 331-348.

Karakayali, S. (2017). Feeling the scope of solidarity: The role of emotions for volunteers supporting refugees in Germany. Social Inclusion, 5(3), 7-16. https://doi. org/10.17645/si.v5i3.1008

Kasparek, B., \& Speer, M. (2015, September 9). Of hope. Hungary and the long summer of migration. Bordermonitoring.eu. Retrieved from http:// bordermonitoring.eu/ungarn/2015/09/of-hope-en

Koopmans, R. (2007). Who inhabits the European public sphere? Winners and losers, supporters and opponents in Europeanised political debates. European Journal of Political Research, 46(2), 183-210. https:// doi.org/10.1111/j.1475-6765.2006.00691.x
Koopmans, R., \& Statham, P. (1999). Political claims analysis: Integrating protest event and political discourse approaches. Mobilization: An International Journal, 4(1), 203-221.

Lahusen, C., \& Grasso, M. (Eds.). (2018). Solidarity in Europe: Citizens' responses in times of crisis. Cham: Palgrave Macmillan.

Leifeld, P. (2016). Policy debates as dynamic networks: German pension politics and privatization discourse. Frankfurt: Campus.

Leifeld, P., \& Haunss, S. (2012). Political discourse networks and the conflict over software patents in Europe. European Journal of Political Research, 51(3), 382-409. https://doi.org/10.1111/j.1475-6765. 2011.02003.x

Musarò, P., \& Parmiggiani, P. (2017). Beyond black and white: The role of media in portraying and policing migration and asylum in Italy. International Review of Sociology, 27(2), 241-260. https://doi.org/10.1080/ 03906701.2017 .1329034

Nossek, H., Adoni, H., \& Nimrod, G. (2015). Is print really Dying? The state of print media use in Europe. International Journal of Communication, 9, 365-385.

Reinemann, C., Stanyer, J., Scherr, S., \& Legnante, G. (2012). Hard and soft news: A review of concepts, operationalizations and key findings. Journalism, 13(2), 221-239. https://doi.org/10.1177/ 1464884911427803

Rheindorf, M., \& Wodak, R. (2018). Borders, fences, and limits-Protecting Austria from refugees: Metadiscursive negotiation of meaning in the current refugee crisis. Journal of Immigrant \& Refugee Studies, 16(1/2), 15-38. https://doi.org/10.1080/15562948. 2017.1302032

Salgado, S., \& Nienstedt, H.-W. (2016). Euro crisis and plurality: Does the political orientation of newspapers determine the selection and spin of information? European Journal of Communication, 31(4), 462-478. https://doi.org/10.1177/0267323116659977

Sangiovanni, A. (2013). Solidarity in the European Union. Oxford Journal of Legal Studies, 33(2), 213-241. https://doi.org/10.1093/ojls/gqs033

Stjern $\varnothing$, S. (2009). Solidarity in Europe: The history of an idea. Cambridge: Cambridge University Press.

Süddeutsche Zeitung. (2014, November 26). Franziskus: Europa ist krank; Egoistische Lebensstile, hemmungsloser Konsum, Einsamkeit im Alter [Pope Francis: Europe is ill: Egoistic lifestyle, unrestrained consumption, loneliness in old age]. Süddeutsche Zeitung. Retrieved from www.factiva.com

TransSOL. (2018). Integrated report on transnational solidarity in the public domain (Working Paper, No. 5). Siegen: TransSOL.

Van Dalen, A. (2012). Structural bias in cross-national perspective: How political systems and journalism cultures influence government dominance in the news. The International Journal of Press/Politics, 17(1), 32-55. https://doi.org/10.1177/1940161211411087 
van der Pas, D. J., van der Brug, W., \& Vliegenthart, R. (2017). Political parallelism in media and political agenda-setting. Political Communication, 34(4), 491-510. https://doi.org/10.1080/10584609.2016. 1271374

Vollmer, B., \& Karakayali, S. (2018). The volatility of the discourse on refugees in Germany. Journal of Immigrant \& Refugee Studies, 16(1/2), 118-139. https:// doi.org/10.1080/15562948.2017.1288284

Wallaschek, S. (2018). Umkämpfte Solidarität und die Krise der EU [Contested solidarity and the crisis of the EU]. Zeitschrift für Politik, 65(4), 413-420. https:// doi.org/10.5771/0044-3360-2018-4-413

Wallaschek, S. (2019). The discursive construction of solidarity: Analysing public claims in Europe's migra- tion crisis. Political Studies. https://doi.org/10.1177/ 0032321719831585

Welt. (2014, October 1). Neuer EU-Innenkommissar will Südländern helfen [New EU commissioner for Justice and Home Affairs will support Southern member states]. Die Welt. Retrieved from www.factiva.com

Zaun, N. (2016). Why EU asylum standards exceed the lowest common denominator: The role of regulatory expertise in EU decision-making. Journal of European Public Policy, 23(1), 136-154. https://doi.org/ 10.1080/13501763.2015.1039565

Zaun, N. (2018). States as gatekeepers in EU asylum politics: Explaining the non-adoption of a refugee quota system. JCMS: Journal of Common Market Studies, 56(1), 44-62. https://doi.org/10.1111/jcms.12663

\section{About the Author}

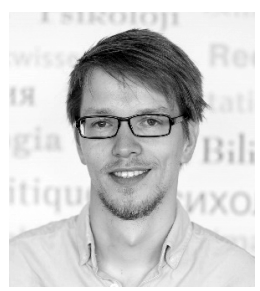

Stefan Wallaschek is a PhD Fellow at the Bremen International Graduate School of Social Sciences (BIGSSS) at the University of Bremen and a Research Associate at the University of Hildesheim. His dissertation investigates the discursive construction of solidarity in Europe in times of crisis. His research focuses on European politics, European politcal sociology, migration and refugee studies, political communication as well as theories of solidarity. 